\title{
ORGANIZATIONAL FACTOR AS BASIC ELEMENTS OF THE ESTONIAN YOUTH WORKERS' PROFESSIONAL GROWTH
}

\author{
Maarika Veigel \\ Tallinn Health Care College Tallinn University, Estonia
}

\begin{abstract}
The issue of the Estonian youth workers' professionality has been relevant for many years. Organizational factors are important in the youth worker's professional growth. Youth worker is a promoter of non-formal education. Research explained the issues related to the youth workers professional growth, including organizational factors. The theoretical framework of the research created Ruohotie, Tamm concepts of professional growth and Hackman, Oldham job satisfaction characteristics. The purpose of this research was brought to the light youth work specialists' opinions about the organizational factors of the professional growth. For qualitative data collection semi-structed interviews were conducted with 35 Estonian youth work specialists in 2016-2018. The results showed that in eight keytopics important opinions were received. Most attention should be given further to the beginner youth workers' support for efficient and faster adaptation with work. Mostly were explained interviewees high satisfaction with team and colleagues. Interviews revealed a different commitment to work, which depends of the employee's professional awareness and involvement in initiatives, that could have resulted from different education, professional training or personal characteristics. The quality of the feedback is important for the employee's professional growth. Individualisation of the work may create a threat to versatility. For further clarification: youth workers' professional identity.
\end{abstract}

Keywords: Estonia, organizational factors, professional growth, youth work, youth worker.

\section{Introduction}

Youth work (YW) is undoubtedly a profession in its' most important and socially necessary sense (Devlin, 2012). The field of YW has made a significant leap forward since the restoration of Estonian independence and is autonomous and in its' decisions autonomous, too. The degree of freedom is higher at the local level than at the national level. While the Estonian YW organization has been recognized in the European Union level, Future Policy Award 2019, the constant turnover of youth workers is a major problem and their professional growth is rather unclear.

In Estonia YW has developed as field that is regulated and standardized. That can be considered as development of YW profession, which is reflected in certain approaches to youth worker skills and values, professional organizations, 
and certain developed expectations of outcomes (Kötsi, 2017). Youth worker organizing YW, leading YW organizations or agencies. The content of his work is individual work with young people or youth groups to engage them in nonformal learning activities and create the conditions for developing entrepreneurship and responsibility. The youth worker guides the process of non-formal learning for young people by creating conditions for the diverse development of youth and supporting their socialization. He creates a trusting relationship with young people and works with them, their parents, other stakeholders and professionals in the field. He develops the YW in his organization in co-operation with his colleagues (Mets \& Viia, 2018; Veigel, 2017). Non-formal learning (NFL) can complement formal learning, providing different outcomes, using the learning and practice centred methods. The blurring of borders between formal, non-formal and informal learning will require new teaching skills and constant evolution of the youth workers profiles. The range of skills required is widening, as youth workers are expected to deal with challenging patterns of behaviour or social issues such as special educational needs and cultural diversity (European Commission, 2015). Young people today face increasing inequalities and high levels of public debt (OECD, 2018; Coppola \& O’Higgins, 2015). Unemployment, in turn, increases social exclusion (Coppola \& O’Higgins, 2015; Williamson, 2005). For example, older young people can be targeted for training, job opportunities or existing services. (Beck, 2015). These aspects must certainly also be in the focus of youth workers.

During 2005-2018 various studies showed the high mobility of Estonia youth workers in youth centres and shortage of personnel with special education. Considering the above, professional youth workers will need long-term employment in the sector to develop and hone their skills (Conradsen, 2017; Veigel, 2015). The purpose of this research was brought to the light YW specialists' opinions about the organizational factors of the professional growth.

\section{Theoretical background}

Youth workers' professional growth as a professional perspective is an important research subject and essential to understand its' basic elements. Professional growth is a natural part of human life, because it supports the coping with work tasks. Ruohotie (2005) said, that this is an ongoing learning process for working life knowledge and skills necessary to obtain that come using the official competent to handle changing requirements. Professional growth basic elements were personality, work-related and organizational factors (work atmosphere; management techniques and practices, which provide the context for development; supportive and challenging situations) (Tamm, 2008; 
Ruohotie, 2005). Professional growth supports worker's job performance. That is a continuous learning process to acquire the knowledge and skills needed for working life, which will be used more competently to meet the changing requirements of the agency (Tamm, 2008; Ruohotie, 2005). We treat professional growth similarly to professional development. Wermke (2011) explained professional development as a process, what is related to coping with change. He takes a broader approach to professional development by arguing that professional development is collaborative, and that emotional intelligence, in addition to knowledge and skills, changes. Good collegial relations, professional understanding, awareness and clarity of duties are essential for successful cooperation. In addition, autonomy supports professional development. Taking responsibility is important for employees with different backgrounds. It is necessary that professional development learning activities provide opportunities to learn new content and skills on an ongoing basis, but also to reflect on their relationship with practice and integrate new knowledge with existing professional practice and habits (Bredeson 2002). Professionals prefer non-formal learning opportunities: collaborative exploration of their practice, discussions with colleagues, different experiences, new assignments, traveling etc. (Veigel, 2017; Bredeson 2002; Daley 1999). Continuous professional development is the retention and improvement of knowledge, expertise, personal and professional competence throughout a career, according to a plan that is tailored to the wishes and needs of the professional, employer and professional associations, and the individual's competences throughout his/her working life (Bailey, 2011).

Over-regulation can reduce the flexibility and innovation of $\mathrm{YW}$ by focusing only on what is provided in the standard. Likewise, closure policies should not eliminate youth-specific work practices such as supporting youth activism, voluntary participation, or youth-to-youth and other YW methods. Standardization should not run counter to the principles of YW (Kötsi, 2017). However, employers have started to pay more attention to the professional education of youth workers. In the everyday practice of youth workers, theoretical knowledge is often not widely used. Not all students of the specialty, after graduation, enter the field of YW. Therefore, in YW studies must to consider how to support the readiness and motivation of students of YW speciality (Veigel, 2017; Veigel, 2015; Kötsi, 2017), to support professional development already at this stage more effectively. By 2021 year in Estonia 198 000 young people will have participated in youth work services. Author recommend strength-based management (Clifton Stenghts), which also supports a value-based approach. Values are the advantages of an institution. An employee-centred model is also the creation of an environment, where the employee is respected and cared for in turn to support young people. 
In order to increase job satisfaction, reduce employee turnover and absenteeism, it is necessary to take into the focus all five indicators when applying the job characteristics model: job diversity, job specify, job relevance, autonomy, feedback (Hackman \& Oldham, 1975). All aspects can be skilfully addressed organizationally. As to the YW field entered workers with very different backgrounds and professional knowledges (Veigel, 2018), it is important that the team, as well as the manager, professionally support their professional growth from the adjustment to the next working life. It is also important to understand the organizational culture, which is a set of attitudes, beliefs, values and norms that members of the organization share. These are key elements of the work environment. It gives the employee an organizational identity. It is also a source of stability and consistency, providing employees with a sense of job security. Knowledge of organizational culture helps new employees better understand what is happening in the organization. Probably more than anything else, organizational culture helps stimulate employees' enthusiasm for their tasks. Managers are interested in attitudes related to employees' work. The three most common of these are: job satisfaction, work commitment and organizational loyalty. Job satisfaction is the general attitude of an employee towards their job. When people talk about employee attitudes, they usually point to job satisfaction. Job involvement is the degree to which a person identifies with their work by actively participating in it and by attaching the result of their work to their self-worth. Organizational commitment demonstrates employee loyalty, identification and commitment to the organization. (Mägi, 2011) The low self-confidence of employees can be increased by empowerment. Empowerment is any process that gives employees greater autonomy by sharing relevant information and gaining control over factors that affect their performance. Empowerment helps eliminate the conditions that cause disability. Empowerment enables employees to control problems as they arise.

Leadership plays an important role in managing the organization. While a leader is expected to employ subordinates first and foremost, a good leader is also a leader who subordinates want to follow. A leader influenced employees to work towards common goals (Aru, 2001).

Maslach and Leiter (1997) described six areas of work in an organizational context coming together and encompassing major organizational antecedents of burnout. These areas were: workload, fairness, control, community, reward and values. Accordingly, burnout arise from mismatches between people and their work settings manifesting in six areas (Leiter \& Maslach, 1999). Organizational trust, which simply reflect employees' willingness to be vulnerable to their organizations' actions (Paliszkiewicz, 2011), as a transmitting mechanism. 
Accordingly, this degree of vulnerability increased in situations where parties are interdependent to each other.

Workload refers to individuals' expended energy and consumed time at work. In other words, it is the perception of job demands relative to one's limits. Control is regarded as one of the most important organizational factors. Lack of control is believed to occur when employees have insufficient authority over work or are unable to shape their work environment in a way consistent with their values. Community reflects the overall quality of workplace social interactions. More specifically, it is related to how people support each other and work as a team. Reward refers to what extent monetary, social, and intrinsic rewards are consistent with expectations. Value is related to the congruence between an organization's goals and expectations and those of its employees. It emphasizes the motivational connection between an individual and his workplace that goes beyond the utilitarian exchange of time for money. (Leiter \& Maslach, 2004; Maslach \& Leiter, 1997). In the context of organizational predictors of emotional exhaustion, perceived inequity has emerged as a powerful source.

\section{Methodology of research}

This research applies a qualitative research strategy, based on a phenomenological approach. For qualitative data collection semi-structured interviews were conducted with a total of 35 Estonian youth workers and experts (youth centres/YC/directors, YW coordinators); 5 men and 30 women from 14 counties, mostly worked in cities. Pilot interview was conducted with youth worker and the other with YC director, who had over four years work experience. After this the questions were developed and clarified. Interviews were conducted individually in 2016-2018. They lasted usually from 1 to $2 \mathrm{~h}$ and were recorded on tape. The interviews were carried out in a quiet place at the university or at work. This was considered important in order to maintain objectivity and to create an atmosphere in which interviewees would not were afraid to share their experiences and to express viewpoints that might be critical of their study experiences. The interview takes place in a social context. Both the interviewer and the interviewee brought to an interview with their past, age, position, expectations and beliefs (Singleton \& Straits, 2012; Wengraf, 2001). Interviews allowed people to freely talk about their lives with their own words and personal, intimate communication between researchers and interviewees (Kvale, 2006). A common understanding will be created during the interview. A qualitative research method is justified, because the author investigated peoples' judgments and interpretations of the phenomenon (youth workers' professional growth factors) (Vidich \& Lyman, 2003). Data-driven thematic analysis process 
included six phases. First, all recorded interviews were transcribed, read and initial ideas noted. Next, initial codes were generated regarding the phenomenon. In the third phase, the different codes were sorted into potential sub-themes and key-topics. Subsequently, the content of the created sub-themes and main themes were checked. In the fifth phase, all key-topics (8) and subthemes (43) (Table 1) were refined and named. In the last phase, the final analysis was written. In the focus of the research were organizational elements as youth workers' professional growth basics.

The anonymity of the sample was ensured. Protecting participants and respecting their right to make decisions regarding their participation were the core ethical principles guiding the treatment of the participants in the research. The participants were informed of the purpose of the research. Participation was voluntary. Furthermore, participants were informed of their right to withdraw at any time without consequences. No sensitive questions were asked. Saturation of the data was achieved (Creswell, 2005).

\section{Results}

Work atmosphere. Mostly were explained interviewees high satisfaction with colleagues and team, what was an important factor in supporting professional growth. „Getting along with colleagues is great”. Ordinary work was supported daily enough by the managers, but it must be more empowered. Often was mentioned noisy atmosphere in work rooms and overwork during camps/events.

Management techniques and practices. Interviews revealed a different commitment to work, which depends of the employee's professional awareness. Most attention should be given further to the beginner youth workers' support for efficient and faster adaptation with work and to the empowering employees generally. „Would like to see just more integration across disciplines, it seems, that there is still little to gain". YC directors' leadership skills must be developed.

Supportive and challenges situations. Youth workers'external motivation supported rather by colleagues and youth. „The specifics of YW are very diverse and interesting, but often lack the skills to do it”. „Events and youth behavior are challenging enough, as well as writing projects”. „Professionals contributed to the important youth programs, such as Tugila, Nopi üles! (Take up!) and others”. "Flexible worktime is suitable for some employees”. „Altruism may sometimes occurred and overwork, for example, in camps”.

Diversity of work. Multidimensional work should ensure routine work. Involvement and initiatives were important, that could have resulted from different education, professional training or personal characteristics. „There 
should be more innovation in YW”. „Different events and cooperation are as challenges for especially non-educated workers”. „Youth workers' professional skills often seems to make work as a hobby, more pleasant”. „YW is a very wide area".

Work delimitation and job specify. It was confirmed that many youth workers were rather free in their work tasks. Individualisation of work may create a threat to versatility. It was noted, that youth workers were often onesided, less innovative. Youth workers' functional and less attitudinal development needs to be addressed. „YW also offers thousands of opportunities”. „It seems like often doing things, that have been done all the time”. „Youth work is varied and depends of goal settings”.

Job importance. The number of young people involved in YW and were as a good prerequisite for $\mathrm{YW}$ trainings and finding staff. YW was often undervalued. Youth workers themselves must more value their work and professionalization, too.

Table 1 Main key-topics and sub-themes that constitute the pattern of meanings the youth workers attributed to the organizational factors and job satisfaction

\begin{tabular}{|c|c|}
\hline Key topics & Sub-themes \\
\hline \multirow[t]{5}{*}{$\begin{array}{l}\text { Work } \\
\text { atmosphere }\end{array}$} & $\begin{array}{l}\text { Good and rather pleasant work atmosphere with collegues } \\
\text { Often quite noisy atmosphere in work rooms and overwork during } \\
\text { camps/events }\end{array}$ \\
\hline & $\begin{array}{l}\text { Ordinary work is supported daily enough by the managers } \\
\text { Youth satisfaction and good feedback motivated mostly youth workers }\end{array}$ \\
\hline & Internal motivation is a causal (related to pleasurable activities) \\
\hline & More staff ressourses would supported training \\
\hline & Staff shortages affect the professionalisation of the sector \\
\hline \multirow{5}{*}{$\begin{array}{l}\text { Management } \\
\text { techniques } \\
\text { and } \\
\text { practices }\end{array}$} & $\begin{array}{l}\text { YW has high expectations and youth workers'empowement is useful } \\
\text { Clarity of duties must be more YW specific and in developing } \\
\text { YC directors valuing youth work basics and NFL activities }\end{array}$ \\
\hline & YC organisational culture was quite similar \\
\hline & $\begin{array}{l}\text { Managers are supportive but do not deal enough in supporting the } \\
\text { professional development of employees }\end{array}$ \\
\hline & YC directors' leadership skills must be developed \\
\hline & $\begin{array}{l}\text { Experts had expectations related to greter professionality, but they must be } \\
\text { more active }\end{array}$ \\
\hline \multirow[t]{3}{*}{$\begin{array}{l}\text { Supportive } \\
\text { and challenge } \\
\text { situations }\end{array}$} & $\begin{array}{l}\text { Different special trainings leading by youth agency, organizations were } \\
\text { possible } \\
\text { Rather few innovations in YW activities generally and in smart YW } \\
\text { Mostly project-based YW, rather has increased }\end{array}$ \\
\hline & Flexibility was appropriated for the elderly and half-part time workers \\
\hline & $\begin{array}{l}\text { Well-established volunteers were a notable help force } \\
\text { Rather external motivation, supported by the outside (colleagues) }\end{array}$ \\
\hline
\end{tabular}


Veigel, 2020. Organizational Factor as Basic Elements of the Estonian Youth Workers' Professional Growth

\begin{tabular}{|c|c|}
\hline & $\begin{array}{l}\text { Networking and its' possibilities varied locally, but supported youth } \\
\text { workers }\end{array}$ \\
\hline & $\begin{array}{l}\text { 2-4 years experienced worker had theoretical knowledge for practical work } \\
\text { and more innovative views }\end{array}$ \\
\hline $\begin{array}{l}\text { Diversity of } \\
\text { work }\end{array}$ & $\begin{array}{l}\text { Multidimensional work should ensure routine work } \\
\text { Contact abundance created prerequisites for innovation }\end{array}$ \\
\hline & Camps were as good method, but customer dependency \\
\hline & Pleasant tasks and possibility to choise options were revealed \\
\hline & Project-based approach and lack of contact-work were more often \\
\hline & Event-based approach and rather internally short-term motivation \\
\hline & $\begin{array}{l}\text { Less experienced youth workers tended to be more as guards or rely on } \\
\text { their own special skills (sport, art, photo, culture etc) }\end{array}$ \\
\hline $\begin{array}{l}\text { Work } \\
\text { delimitation }\end{array}$ & $\begin{array}{l}\text { Experts have a strict framework based on regulations } \\
\text { Experts' activities depended of the direction of the EU }\end{array}$ \\
\hline $\begin{array}{l}\text { and job } \\
\text { specify }\end{array}$ & $\begin{array}{l}\text { Many youth workers were rather free in their work tasks } \\
\text { Individualisation of work may create a threat to versatility } \\
\text { Youth workers were often one-sided, less innovative } \\
\text { Youth workers'functional and less attitudinal development was necessary }\end{array}$ \\
\hline & Youth workers must themselves to value their work and professionalization \\
\hline importance & Youth work was often undervalued \\
\hline Autonomia & $\begin{array}{l}\text { Rather noticeable, desire to be more autonomous } \\
\text { Difficulties were caused by the financial ressourses and special knowledges }\end{array}$ \\
\hline & Less powed in the cases of YW experts at the municipal level \\
\hline Feedback & $\begin{array}{l}\text { Often immidiatly, but also by plan, mostly weekly, rather in generalized } \\
\text { form }\end{array}$ \\
\hline & $\begin{array}{l}\text { Feedback is important for the employee's professional growth, must be } \\
\text { more quality and to support professional development }\end{array}$ \\
\hline & $\begin{array}{l}\text { Mainly event or project-based feedback, very generalized; need more } \\
\text { reflection(skills) }\end{array}$ \\
\hline
\end{tabular}

„Orientation towards society and quality is important”.

Autonomia. It turned out that youth workers were relatively free to decide on their work. Their freedom was most affected by economic conditions and their professional knowledge. The impact of bureaucracy on the field was increased by EU regulations and growing standardization. „You are free in your activities, but you have to follow certain rules”. „The limitation is rather the employees' own spectrum of competences".

Feedback. Revealed that feedback must be more quality and support better professional development. „In many cases, feedback did not work as intended, is a commitment rather than an educational one”. "Feedback is often like 'fashion', but we need better reflection skills for that". Supporting the youth workers' professional development must be part of the long-term plans (e.g. training programs). Important issues were targeting job and job analysis. 


\section{Conclusion}

YW profession characteristics difference from other related fields (NFL), useful and rather altruistic ideology, values, ethics; orientation towards society; appropriate trainings, self-development and orientation to the quality. It turned out that, YW experts must express about work achievements, their needs confidently and more loudly. More attention should be paid to the needs for developing leadership skills of YC directors and possibilities for youth workers' trainings. Revealed that YW experts must more valued professional work and create opportunities for better YW content activities. More could be done for motivating employees, including "retaining", because experts also believed that YW was a suitable platform for advancement (school, trainer, etc.) in terms of content and learning diversity. Youth workers were generally relatively free to decide on their work. Multidimensional work should ensure routine work, but youth workers must be more innovative, e.g. use smart YW methods for achieving necessary educational goals in NFL.

Working in the local government set a certain framework for experts, who understood the content of the YW, but it is hard to training and mentoring many new colleagues constantly. Reflective activities, which help to combine the professional and personal aspects of being a youth worker, supporting to develop professional identity, must be strongly amplified in the focus. Collegiality and organizational culture supported employees, but attention should be pay more to the other elements of professional growth (personal and work-load factors), too. Empowerment enables employees to control problems as they arise. The low self-confidence of employees can be increased by empowerment. There was rather few organizational loyality. In the future strength-based management will recommend, which also support a value-based approach.

The study limitation was qualitative methodology, which does not allow for extensive generalizations, but it was necessary to obtain the information that with other methods would have been difficult. This topic should be explored further in the aspects of professional identity.

\section{References}

Aru, H. (2001). Strateegiline juhtimine avalikus sektoris. Strategic management in the public sector, 36. Eesti Haldusjuhtimise Instituut. Estonia.

Bailey, M. (2011). Policy, professionalism, professionality and the development of HR practitioners in the UK. Journal of European Industrial Training, 35, 487-501.

Beck, V. (2015). Learning providers' work with NEET young people. Journal of Vocational Education \& Training, 67(4), 482-496. 
Bredeson, P.V. (2002). The architecture of professional development: materials, messages and meaning. International Journal of Educational Research, 37(8), 661-675. DOI: 10.1016/S0883-0355(03)00064-8

Conradsen, N.B. (2017). Estonia. Taking the future into their own hands. Youth work and entrepreneurial learning. Annex 1: country reports. In Andersen, T., Hougaard, K.F. (Eds.), Directorate -General Education, Youth, Sport and Culture (pp. 90-97). European Commission.

Coppola, G., \& O'Higgins, N. (Eds.). (2015). Youth and the crisis: Unemployment, education and health in Europe. Routledge.

Creswell, J.W. (2005). Educational Research. Planning, Conducting, and Evaluating Quantitative and Qualitative Research. Pearson Education International, 354 - 357.

Daley, B.J. (1999). Novice to Expert: Exploration of How Professionals Learn. Adult Education Quarterly, 49(4), 133 - 147.

Devlin, M. (2012). Youth work, professionalism and professionalisation in Europe. In: The history of youth work in Europe. Relevance for youth policy today, Coussee, F., Williamson, H., Verschelden, G. (Eds.), 3, 177-190.

European Commission. (2015). Youth work and non-formal learning in Europe's education landscape, 2-3.

Hackman, J.R., \& Oldham, G.R. (1975). Development of the Job Diagnostic. Survey. Journal of Applied Psychology, 60(2), 159-170.

Kvale, S. (2006). Qualitative Inquiry: Dominance through Interviews and Dialogues, 12(3), 480-500. DOI: https://doi.org/10.1177/1077800406286235

Kötsi, K. (2017). Noorsootöö kui professioon. Noorsootöö professionaliseerumine. (Youth Work as a profession. Professionalisation of the youth work), Tallinna Ülikool, 55-56, Estonia.

Leiter, M.P., \& Maslach, C. (1999). Six areas of worklife: A model of the organizational context of burnout. Journal of Health and Human Services Administration, 21(4), 472489. Retrieved from http://www.jstor.org/stable/25780925

Leiter, M.P., \& Maslach, C. (2004). Areas of worklife: A structured approach to organizational predictors of job burnout. In P. Perrewé \& D.C. Ganster (Eds.), Research in occupational stress and well-being, 3 (pp. 91-134). Oxford, UK: Elsevier.

Maslach, C., \& Leiter, M.P. (1997). The truth about burnout. New York, NY: Jossey-Bass.

Mets, U., \& Viia, A. (2018). Tulevikuvaade tööjõu- ja oskuste vajadusele: haridus ja teadus. (Future view on labor and skills need: education and science). Uuringu lühiaruanne. Tallinn: SA Kutsekoda, 14, 30-31.

Mägi, J. (2011). Organisatsioon ja juhtimine. Organisatsioonikäitumine. Organization and management. Kuressaare Ametikool. Estonia. Retrieved from http://web.ametikool.ee/ jane/okj/?Avaleht

OECD. (2018). Youth Stocktaking Report.

Paliszkiewicz, J.O. (2011). Trust management: Literature review. Management, 6(4), 315-331.

Ruohotie, P. (2005). Oppiminen ja ammatillinen kasvu. (Learning and professional growth). Helsinki: Werner Söderström Osakeyhtiö.

Singleton, R.A., \& Staits, B.C. (2012). Survey interviewing. Interwiev research. The SAGE Handbook. Gubrium, J.F., Holstein, J.A., Marvasti, A.B., Mc Kinney, K.D. (Eds.), 7798. Library of Congress Cataloging - in - Publication Data. United States of America. 
Proceedings of the International Scientific Conference. Volume V, May $22^{\text {th }}-23^{\text {th }}$, 2020. 302-312

Tamm, T. (2008). Ametikasv ja professionaalsus. (Professional growth and professionalism). Õpik sotsiaaltöö eriala üliõpilastele ja teistele huvilistele. Tallinna Ülikooli kirjastus, Estonia

Veigel, M. (2018). Estonian youth workers' professionality: youth centers' directors and youth field coordinators opinions. SGEM proceedings, 5(3.4), 307-317.

Veigel, M. (2017). Youth workers' professional growth. Science and society, SGEM proceedings, 3(4), 749-756.

Veigel, M. (2015). Formation of youth worker professionalism: Problems in Estonia. Problems of Education in the 21st Century, 68, 84-96.

Vidich, A.J., \& Lyman, S.M. (2003). Qualitative Methods: Their History in Sociology and Anthropology. Retrieved from http://jan.ucc.nau.edu/ pms/cj355/readings/vidich\& lyman.pdf

Wengraf, T. (2001). Qualitative Research Interviewing. London, Thousand Oaks, New Delhi: Sage Publications.

Wermke, W. (2011). Continuing professional development in context: teachers' continuing professional development culture in Germany and Sweden. Professional Development in Education, 37, 665-683.

Williamson, H. (2005). Young People and Social Inclusion-An overview of policy and practice. Youth Policy and Social Inclusion: Critical debates with young people, 11-27. 